\title{
In search of a working notion of Lex Sportiva
}

\section{By Alfonso Valero}

\section{Senior Lecturer at Nottingham Law School (Nottingham Trent University)}

\author{
Nottingham Law School \\ Nottingham Trent University \\ Burton Street \\ Nottingham NG1 4BU \\ Tel: +44 1158486197 \\ E-mail: alfonso.valero@ntu.ac.uk
}

\begin{abstract}
$\underline{\text { Abstract }}$
The emergence of a lex specialis regime and its interaction with the established, governing lex generalis in their overlapping spheres of application is always an intriguing legal relationship to explore. In this article, the focus will be on the development of legal principles and rules that has/can be collectively described as lex sportiva. However, it is notable that those involved in the consideration, usage and application of this notion have not agreed as to the scope and delimitation of the concept. It is debated whether lex sportiva exists in the first place, its legal sources and its purpose. The risk is for the concept becoming redundant when not vilified as a hidden strategy to exclude non-sports-related law from the ambit of sport. Through an examination of the different propositions to the framework of the term, this article will shed light on the existence, utility and limits of the development of this conceptualisation.
\end{abstract}




\section{Introduction}

The natural impulse of any emerging branch of law is to define itself by delimiting its area of influence by comparison to other more established areas. In that struggle it is almost unavoidable attempting to fence off the influence of public policy or mandatory provisions in a sort of becoming-of-age legal ritual. That is the context where the lex sportiva finds itself at the moment: a look to the past - with a reminiscence of traditional roots of the lex mercatoria -, an orientation to the future - consolidation of the Court of Arbitration for Sport (CAS)-, and a gained confidence in its existence - echoed in a virtually non-existent challenge to its effects -.

Against that background, it is noticeable to realise that, very much like the lex mercatoria, lex sportiva is not an agreed concept and its scope and its neighbour-relations with public policies have not been considered properly. In particular, when it comes to EU mandatory rules, the principles deduced from the arbitral awards have been, at best, contradictory, when not straightforward confrontational.

Two factors cannot be ignored: one, that lex sportiva is the lex specialis of a specialised branch of the law, namely, Sports Law; second, that the term lex sportiva has a deliberate abstract component part of this search for legitimacy.

This article attempts to outline the problems with suggested meanings of the idea, problems with its demarcation and suggests its right place in the world of arbitration of sport-related disputes.

\section{The problem with the lack of definition of lex sportiva.}

There is a certain misleading assertiveness in relation to the understanding of the scope and definition of lex sportiva. Amongst the most vocal supporters Michael Lenard, member of the International Council of Arbitration for Sport, ${ }^{1}$ which oversees and operates the Court of Arbitration for Sport believes that the time for discussion on the existence of a lex sportiva has now passed. ${ }^{2}$ His opinion is founded on the fact that CAS opinions or briefs submitted to it cited previous opinions of the same tribunal dealing with sports regulations. This is hardly evidence of lex sportiva. Self-citation (CAS to its own previous awards), invoking previous decisions (by the parties in dispute before CAS) or uniform reading of sports regulations don't prove the existence of lex sportiva, certainly not, as the cited author implies, lex sportiva as the body of CAS awards.

\footnotetext{
${ }^{1}$ As of January 2014

${ }^{2}$ Michael Lenard, 'The Future of Sports Dispute Resolution'. [2009-2010] 10/1 Pepperdine Dispute Resolution Law Journal, 179.
} 
The difficulty is that this conceptualisation- i.e. the precedents of the CAS - is only shared in the American literature, ${ }^{3}$ and not even uniformly. ${ }^{4}$ Even assuming that the majority of the North American CAS' arbitrators shared Lenard's view, they only represent a $14 \%$ of the total. ${ }^{5}$ Perhaps the debate cannot be about the existence, but it certainly needs to be about its nature since the consequences can be substantial since it is expected to affect any party involved in a sports-related dispute, whether it is before CAS or another panel, whether it is a regulatory issue (e.g. doping) or more commercial.

Certainly, not all of the panellists of CAS are convinced of the extent of the lex sportiva. To that end the Advisory opinion Fédération Internationale de Football Association (FIFA) \& World Antidoping Agency provided to FIFA in relation to its obligation to amend its Anti-doping rules to comply with WADA Code, it expressly said '[t]he exact content and the boundaries of the concept of a lex sportiva are still far too vague and uncertain to enable it to be used to determine the specific rights and obligations of sports associations towards athletes' ${ }^{6}$

When it comes to use the notion of lex sportiva, there are roughly two dividing lines. Those who want to use the concept of lex sportiva, taking the words of Denning L.J. in Combe $v$ Combe, as a shield and as a sword, ${ }^{7}$ carving out an area free from government regulation and also relying on it to override any resource to dispute resolution mechanisms or protection of the national or supranational law; and those who seek to determine the elements that are unique and distinctive of sport and which need to be preserved.

For the former group the ultimate goal of the lex sportiva is, as expressed by Beloff and Beloff, 'to immunise sport from the reach of the law, to create, in other words, a field of autonomy onto which even appellate sports tribunals should not trespass' ${ }^{8}$

Under that perception, the blanket of the lex sportiva seems to be stretched almost capriciously calling for assistance from the governments (for example, the fight against doping consolidated in the International

\footnotetext{
${ }^{3}$ Matthew J. Mitten and Hayden Opie, “Sports Law”: Implications for the Development of International, Comparative, and National Law and Global Dispute Resolution'. [2010] 85/2 Tulane Law Review, 302; Abbas Ravjani, 'The Court of Arbitration for Sport: A Subtle Form of International Delegation'. [2008-2009] 2/2 Journal of International Media \& Entertainment Law, 284.

${ }^{4}$ Allan Erbsen, 'The Substance and Illusion of Lex Sportiva' in Ian S. Blackshaw, Robert C.R. Siekmann and Janwillem Soek (eds), The Court of Arbitration for Sport, 1984-2004 (T.M.C. Asser Press 2006) 441; Richard H. McLaren, 'Twenty-Five Years of the Court of Arbitration for Sport: A Look in the Rear-View Mirror'. [2010] 20/2 Marquette Sports Law Review, 333; Matthew J. Mitten, 'Judicial Review of Olympic and International Sports Arbitration Awards: Trends and Observations'. [2009] 10/1 Pepperdine Dispute Resolution Law Journal 65; Maureen A. Weston, 'Simply a Dress Rehearsal? U.S. Olympic Sports Arbitration and De Novo Review at the Court of Arbitration for Sport'. [2009] 38 Georgia Journal of International and Comparative Law, 128.

${ }^{5}$ CAS, List of Arbitrators <www.tas-cas.org/arbitrators-genlist > accessed 26 January 2014.

${ }^{6}$ CAS 2005/C/976 \& 986 [124].

${ }^{7}$ [1951] 2 K.B. 215, [1951] 1 All ER 767.

${ }^{8}$ Michael Beloff and Rupert Beloff, 'The Field of Play' in Simon Hetherington (ed), Halsbury's laws of England centenary essays, 2007 (LexisNexis Butterworths 2007) 147.
} 
Convention against Doping in Sport, adopted unanimously by the $33^{\text {rd }}$ UNESCO General Conference on October 19, 2005) while arguing a lack of understanding from the authorities. In their assistance, the supporters of that current of thought often cite the words of Lord Denning MR in Enderby Town Football Club Ltd. v Football Association Ltd - 'better by a good layman than by a bad lawyer' - when back in 1970s, it was accepted a flexible procedure 'in activities like football and other sports, where no points of law are likely to arise, and it is all part of the proper regulation of the game'. ${ }^{9}$ Another common quotation is the understanding of Megarry V-C in 'McInnes $v$ Onslow-Fane and Another' that 'courts must be slow to allow any implied obligation to be fair to be used as a means of bringing before the courts for review honest decisions of bodies exercising jurisdiction over sporting and other activities which those bodies are far better fitted to judge than the courts' ${ }^{10}$ Similar sources are relied on in the US courts, when in Nabozny v. Barnhill the Appellate Court of Illinois made the following observation: "This court believes that the law should not place unreasonable burdens on the free and vigorous participation in sports by our youth. However, we also believe that organized, athletic competition does not exist in a vacuum. Rather, some of the restraints of civilization must accompany every athlete on to the playing field. However, we also believe that organized, athletic competition does not exist in a vacuum. Rather, some of the restraints of civilization must accompany every athlete on to the playing field."11

However, it is convenient to point out that about the same time that the Vice-Chancellor was calling for caution in reviewing decisions of the sport governing bodies, the Privy Council in Calvin v Carr, a matter related to Australian horse racing, ruled that the court will look into the natural justice of the disciplinary proceedings of the sport governing bodies (SGBs). ${ }^{12}$ In fact, back in 1931 the English High Court stipulated that a claimant should be bound by the decisions of the stewards provided that those proceedings are conducted in accordance with natural justice'. ${ }^{13}$

In their pursuance for identity, some authors defending this thesis have gone as far as presenting the CAS as the body that introduced the due process of [law] as a fundamental right in sports law, ${ }^{14}$ or equal treatment and level playing field. ${ }^{15}$ This search for legitimacy seems to rest in the wrong pillars. Firstly, the judgements invoked in assistance of an implied recognition by the courts of a lex specialis, are based precisely in a lack of legal entity to the disputes. Conversely, if the dispute had substantial legal issues to be considered, the court could not accept self-regulation. Secondly, unlike the lex mercatoria, considered as a body of law created by the collective of merchants, the defenders of an autonomous lex sportiva have an excessive CAS-centrism which fails to provide a theoretical underpinning of the proposition because lex sportiva needs to be able to exist on its own. Otherwise no lex specialis would exist outside the organisation or organisations which purports to apply it. It would be as if

\footnotetext{
${ }^{9}$ [1971] Ch. 591, [1970] 3 W.L.R. 1021, 605 para F.

${ }^{10}$ [1978] 1 W.L.R. 1520, 1535 para G.

11334 N.E. 2d 258 (1975)

${ }^{12}$ [1979] 2 W.L.R. 755, 596 para C.

${ }^{13}$ Cookson v Harewood [1932] 2 K.B. 478, 482.

${ }^{14}$ Lorenzo Casini, 'The Making of a Lex Sportiva: The Court of Arbitration for Sport 'Der Ernährer", 12. [2010] <http://dx.doi.org/10.2139/ssrn.1621335> accessed 26 January 2014.

${ }^{15}$ Boxing Australia v. AIBA, CAS 2008/O/1455.
} 
the International Chamber of Commerce International Court of Arbitration purported to create a lex arbitralis which binds those involved with the ICC and which is exclusive creation of its awards. In fact, taking into account that the CAS doesn't have the custom of rejecting matters for not being sufficiently sports-related, ${ }^{16}$ it is ironic that this sort of lex sportiva Midas-like touch of the CAS should expand to purely commercial disputes.

The opposing current of thought tries to provide certainty to the notion of lex sportiva to allow it to develop on a firm foundation. Rather than sports-centrism or, more precisely, CAS-centrism, the approach should be to identify the necessary elements of self-regulation and then recognising the influence - and even the restrictions - imposed by external elements. This line of thought is magnificently represented by Foster, who rejects the wording lex sportiva as 'a dangerous smoke screen justifying self-regulation by international sporting federations' ${ }^{17}$ Instead, Foster proposes the label of global sports law understood as 'transnational autonomous legal order created by the private global institutions that govern international sport'. ${ }^{18}$ Opposite to those theories that promulgate a lex sportiva inclusive of everything that carries the word sport, Foster indicates that the concept needs to be distinctive and unique, and it is circumscribed to the principles that emerge from the rules and regulations of international sporting federations. ${ }^{19}$ For Foster, this system is based on agreement to be subject to the authority and jurisdiction of international sporting federations and its independence from national legal systems. ${ }^{20}$ Against that background, the mission of the CAS is harmonising standards and best practice amongst the international sport governing bodies (IFs). ${ }^{21}$ Otherwise, '[t]he danger for the Court of Arbitration for Sport is that the use of 'lex sportiva' as a concept leads to the position that its principal function as a 'supreme court of world sport' excludes or modifies the other functions that it performs' ${ }^{22}$

\section{A new lex mercatoria?}

As part of this search of legitimacy, the term lex sportiva evokes the lex mercatoria, an image not exempt of controversy. CAS has evoked precisely this parallel in, amongst others, AEK Athens and SK Slavia Prague vs. Union of European Football Associations (UEFA) (ENIC) ${ }^{23}$, Club Atlético Peñarol c. Carlos Heber Bueno Suarez, Cristian Gabriel Rodríguez Barrotti \& Paris Saint-Germain (Bueno \& Rodríguez) ${ }^{24}$ and The Gibraltar

\footnotetext{
${ }^{16}$ McLaren (n 4), 333.

${ }^{17}$ Ken Foster, 'Is there a Global Sports Law'. [2003] 2/1 Entertainment and Sports Law Journal, 17.

${ }^{18}$ Ibid, 2.

${ }^{19}$ Ibid, 4.

${ }^{20}$ Ibid, 2.

${ }^{21}$ Ken Foster, 'Lex Sportiva and Lex Ludica: the Court Of Arbitration for Sport's Jurisprudence'. [2005] 3/2

Entertainment and Sports Law Journal, para 6.

${ }^{22}$ Ibid para 56.

${ }^{23}$ CAS 98/200 [156];

24 TAS 2005/A/983\&984 [66];
} 
Football Association (GFA)/Union des Associations Européennes de Football (UEFA). ${ }^{25}$ Some authors have also assimilated the process of lex sportiva with the lex mercatoria. ${ }^{26}$

Waincymer indicates that one problems of the use of lex mercatoria in commercial arbitration is that "the content usually combines principles that are truly accepted by all civilised countries and other principles that are more aspirational in the context of the proponents' thoughts about the needs of international commerce'. ${ }^{27}$ The author refers a non-exhaustive list of principles some of which are shared with lex sportiva as cited by Parrish: 'the contra proferentem principle, equal treatment, proportionality, due process, the right to be heard and the duty to give reasons' as principles adapted to sport by the lex sportiva.$^{28}$ The difficulty is that while the principles are no doubt beneficial, it lacks specificity and foreseeability. That is why Born warns against the choice of lex mercatoria as applicable law because there is 'little authority about what such clauses mean, and there are doubts how widely they are enforceable (e.g., English courts in particular have expressed reservations)'. ${ }^{29}$ If in the context of international commercial arbitration this reference would not be ideal, it cannot be more advisable for international sports arbitration.

Rodríguez Fernández attempts to explain the suitability of lex mercatoria to commercial relations, bearing testimony of the controversy existing to accept the delimitation of the term. ${ }^{30}$ The sources of this law would be uniform terms and conditions published by international agencies, general terms and assisted by the enforcement of the international arbitration. ${ }^{31}$ In reality, this system of lex mercatoria wouldn't be so inconvenient. The difficulty comes when the parties subject to the dispute are expected to be bound by usages and customs not adhered to in the contract or just not published. With regards to the idea of the arbitrators sifting through the pith of commercial customs, it is distant from reality, since the arbitrators are normally chosen on the basis of their expertise in a specific area. It would be illogical that, for example, a banking expert was asked to adjudicate in a construction or shipping dispute precisely for the specialist nature of the norms. At the same time, the idea of arbitrators as "communicators of law" is against the idea of arbitration as a confidential dispute resolution mechanism.

In reality, the lex mercatoria of Rodríguez Fernández is distant from the idea of commercial law created by the merchants. The international custom that the author adheres to is formulated by international organisations like

${ }^{25}$ CAS 2002/O/410 [4].

${ }^{26}$ Casini (n 14), 11; Mitten and Opie (n 3); Richard Parrish, 'Lex sportiva and EU sports law'. [2012] 37/6 European Law Review.

${ }^{27}$ Jeffrey Waincymer, Procedure and evidence in international arbitration (Kluwer Law International 2012) 1006.

${ }^{28}$ Parrish (n 26) 719.

${ }^{29}$ Gary B. Born, International Arbitration and Forum Selection Agreements: Drafting and Enforcing (Kluwer Law International 2013) 163.

${ }^{30}$ Maximiliano Rodríguez Fernández, 'Reconomiento de la lex mercatoria como normativa propia y apropiada para el comercio internacional'. [2012] 11/2 Revista e-mercatoria, 45 - 89.

${ }^{31} \mathrm{Ibid}, 59$ and 79. 
the International Chamber of Commerce (e.g. Incoterms) or the United Nations (e.g. Uncitral). This model of lex mercatoria transposed to sports would cover the WADA Code ${ }^{32}$, but not the IFs, because they are regulating their sport while assuming control of the commercial opportunities generated. Therefore, this modern lex mercatoria is ill-inspired to sport.

It would be necessary to go the primitive and evocative lex mercatoria, the one allegedly created by the medieval merchants. An extremely thorough research on the existence of lex mercatoria, of Emily Kadens, takes notice of those scholars 'fallen in law with the Middle Ages' in fields including sports law. ${ }^{33}$ Kadens meticulously dismantles the myth of a lex mercatoria as international custom created by merchants of the Middle Ages and demonstrates that in reality the rules arose from contract and legislation. In the author's opinion, ' $[\mathrm{t}]$ he invocation of the term law merchant to refer to a uniform and universal merchant-created customary body of law is an invention of the nineteenth and twentieth centuries'. ${ }^{34}$ Her definition of custom, straight from Bartolus de Saxoferrato, is repeated behaviour to which the community has tacitly consented to be bound ${ }^{35}$ and she points out that ' $[\mathrm{w}] \mathrm{e}$ do not need a special phrase to describe the fact that merchants historically used contracts any more than we need one to describe the same fact now. ${ }^{36}$

Two final salient points for those theorists of the lex sportiva as a new lex mercatoria is that the customs were frequently faked to create a custom once it was accepted by the arbitrators ${ }^{37}$ and 'merchants sometimes had good reason to want an authoritative institution - e.g., court, public legislature, or guild - to establish a rule for them' ${ }^{38}$

Therefore, the traditional perception of lex mercatoria as a custom created rule which would be enforced by special courts and or arbitrators is detached from reality. In fact, the realities of the lex mercatoria provide an interesting lesson for the lex sportiva. The contractual creation of obligations between the parties is not going to be threatened by the national or transnational laws. A great deal of self-regulation needs to be promoted and protected. However, these creations will find gaps and inconsistencies that need to be filled with specific solutions. The reference to general principles will aid in the interpretation of the rule, but a rule needs to exist in the first place. Accordingly, just as for the merchants in the Middle Ages, the complementary use of legislation will provide certainty and resolution.

In reality as Hatzimihail shows, the use of lex mercatoria has nothing to do with the historical accuracy of the concept. In fact, the 'historical revisionism has so far made few inroads among mercatorists or even in the

\footnotetext{
32 WADA, 'World Anti-Doping Code' < $\underline{w w w . w a d a-a m a . o r g / e n / W o r l d-A n t i-D o p i n g-P r o g r a m / S p o r t s-a n d-A n t i-~}$ Doping-Organizations/The-Code/> accessed 27 January 2014.

${ }^{33}$ Emily Kadens, 'The Myth of the Customary Law Merchant'. [2012] 90/5, Texas Law Review, 1153 - 1206.

${ }^{34}$ Ibid 1168.

${ }^{35}$ Ibid 1164.

${ }^{36}$ Ibid 1176.

${ }^{37}$ Ibid $1189-1190$.

${ }^{38}$ Ibid 1196.
} 
mainstream of international business law: the romance of the law merchant still casts a powerful spell' ${ }^{39}$ Analysing the opinions of the fathers of the modern lex mercatoria, Hatzimihail remembers that Schmitthoff wasn't suspicious of the state, which helped to 'further his normative agenda of producing authoritative texts by bringing together customary rules, mercantile practice, and state legislation' while for Goldman 'state law, followed by legal particularism, can only corrupt the law merchant' ${ }^{40}$. The process of lex sportiva, a 'spin-off of the lex mercatoria' follows a very similar procedure as seen above. ${ }^{41}$

In conclusion, the comparison between the two ambitions of transnational law shows that in the apparently innocuous terminology there are two agendas, the ones who want to enhance the ability of self-regulate to exclude other foreign laws and the ones who want to create a legitimate space for a branch of law.

\section{Proposal for a concept of lex sportiva}

The previous sections have been exploring the whys of the framework of lex sportiva. This section tackles the different interpretations of the concept.

\subsection{Lex sportiva as CAS jurisprudence}

In section 2 above it was sketched out that a number of North American authors consider lex sportiva as CAS jurisprudence and the fact that this opinion is debated. CAS panels have also been inclined to share this view. In Canadian Olympic Committee (COC) \& Beckie Scott v. International Olympic Committee (IOC), the panel confirmed that the reliance on CAS precedents by the parties amounts to a choice of law of lex sportiva. ${ }^{42}$

The proposition has two serious flaws and one important risk. The first flaw is the lack of precedent setting intention or indeed capacity; the second, the lack of availability of the awards. The risk is, again, the dubious strength of a body of law which exists no further from the Arbitral Tribunal that holds it as mentioned before. The referred flaws are dealt with next.

Looking at the doctrine of stare decicis or precedent setting, CAS panels concede importance to the previous decisions, but avoid creating an obligation to do so. In International Association of Athletics Federations (IAAF) v. USA Track \& Field, the tribunal expressed an intention to maintain the same conclusions of previous CAS Panels in matters of law, avoiding grounding the reasons for this: ' $[w]$ hether that is considered a matter of comity, or an attempt to build a coherent corpus of law, matters not. ${ }^{43}$ In a more recent decision, Andrea Anderson and others $v$. International Olympic Committee (IOC), the tribunal stated that 'it must accord to previous CAS awards a substantial precedential value and it is up to the party advocating a jurisprudential change to submit persuasive

\footnotetext{
${ }^{39}$ Nikitas E. Hatzimihail, 'The Many Lives — and Faces — of Lex Mercatoria: History as Genealogy in International Business Law'. [2008] 71/3, Law and Contemporary Problems, 173.

${ }^{40}$ Ibid 187.

${ }^{41}$ Ibid 172.

${ }^{42}$ CAS 2002/O/373 [14].

${ }^{43}$ CAS 2004/A/628 [19].
} 
arguments and evidence to that effect. ${ }^{44}$ In other words, the panels will accept submissions relying on previous decisions, but will not admit an expectation to do so in the future. If there was such intention, it would be expectable to see that acknowledgement. Future panels would always be able to draw the differences from previous cases to justify another approach (see, for example, the differences between Wigan Athletic FC v/ Heart of Midlothian, Heart of Midlothian v/ Webster \& Wigan Athletic FC and Webster v/ Heart of Midlothian ${ }^{45}$ and FC Shakhtar Donetsk (Ukraine) v. Mr. Matuzalem Francelino da Silva (Brazil) \& Real Zaragoza SAD (Spain) \& $F I F A^{46}$, when the panel rejected to be overruling any previous decisions and claimed to be following a mandate of FIFA to resolve on a case-by-case basis).

This reluctance by the panels themselves is not coincidental. CAS panellists come from different legal traditions. Binding precedent is generally assumed in the legal tradition of equity (or court-created law) and much less by the called civil law tradition. ${ }^{47}$ While common law practitioners are used to the gap-filling function of the decisions of the courts, civil law lawyers normally take a more persuasive authority approach, trying to present previous decisions as one more argument in the balance. Be it as it may, precedent setting is unheard of in the field of arbitration. Dealing with the value of previous awards in commercial arbitration, Blackaby and others express the lack of binding precedent of arbitral awards saying that the "award of the first tribunal, if it is knownand it may not be known, because of confidentiality—may be of persuasive effect, but no more". ${ }^{48}$ Even accepting a purpose as decisive authority, Born accepts that this 'does not mean that they enjoy binding authority' ${ }^{49}$

With those ambitions of Supreme Court for sport it cannot be surprising that sports law practitioners propose a Grand Chamber of CAS precisely to resolve contradictions between CAS awards and to set precedence. ${ }^{50}$ This proposal implies acceptance by those who operate in the sector that CAS jurisprudence is not a body of law. However, whether a tribunal is formed of three arbitrators or five, it cannot purport to have a higher - for better perspective of the interpretation of the applicable law. That goes against the very nature of arbitration understood as consensual, non-governmental, impartial decision made on the merits of the case, final and binding on the parties. ${ }^{51}$ An arbitral award can be a very persuasive authority, but should not be more than that.

\footnotetext{
${ }^{44}$ CAS 2008/A/1545 [55].

${ }^{45}$ CAS 2007/A/1298, 1299 \& 1300.

${ }^{46}$ CAS 2008/A/1519 \& 1520.

${ }^{47}$ For a general view about the differences between the two legal traditions, see John H. Merryman, The civil law tradition: an introduction to the legal systems of Western Europe and Latin America (Stanford : Stanford University Press 1969).

${ }^{48}$ Nigel Blackaby and others, 'An Overview of International Arbitration' in Redfern and Hunter on International Arbitration (Oxford University Press 2009) pp. 38- 39.

${ }^{49}$ Gary B. Born, International Arbitration: Law and Practice (Kluwer Law International 2012) pp. 365 - 366.

${ }^{50}$ James Segan, 'Does the Court of Arbitration for Sport need a “Grand Chamber”?' (Blackstone Chambers Sports Law Bulletin, 19 April 2013) <http://sportslawbulletin.org/2013/04/19/does-the-court-of-arbitration-forsport-need-a-grand-chamber/> accessed 26 January 2014.

${ }^{51}$ Born (n 47) pp. $3-5$.
} 
Authors who have considered this specific aspect don't go as far as saying that the CAS produces a proper 'case law', understood in the common law rule of precedent setting, but a persuasive precedent in the way of civil law jurisdictions. Mitten asserts that previous decisions serve as guidance to ensure that like cases are treated alike in accordance with Swiss public policy. ${ }^{52}$ McLaren, himself a frequently appointed CAS arbitrator, points out that while there is no obligation to follow previous rulings arbitrators typically do so for the sake of clarity. ${ }^{53}$ The fact that CAS awards refer to previous decisions is completely understandable; a panel dealing with technical issues (for example, doping), or with specialist contractual matters (for example, transfer rules) would seek guidance and reassurance in previous decisions. However it doesn't mean that CAS panels intend to establish a binding precedent.

Intrinsically linked to the issue of binding effect is the second flaw, which is the availability of CAS awards, it needs to be pointed out that while CAS published digests of its decisions, it wasn't until 2009 that CAS started to make available a large number of its award. ${ }^{54}$ It is still a work in progress and confidentiality may still restrict publication of important decisions. CAS awards in appeal (i.e. appeal against decisions of sport governing bodies) are made public, unless both parties agree that they should remain confidential (article R59 of CAS Code ${ }^{55}$ ), but those coming from the ordinary procedure (i.e. arbitration referred to directly by the parties) are meant to be confidential unless both parties agree that they would be published (article R43 of the CAS Code). In those countries with legal tradition of precedent setting, public hearings and case reporting are essential. Lenard considers the importance of publication of CAS awards to improve and refine the lex sportiva, but this is tiptoeing a very essential feature of arbitration, which is confidentiality. ${ }^{56}$ It could be suggested that the awards can be made anonymous, but this is rarely a solution. For example, the decisions of the Dispute Resolution Chamber (DRC) of FIFA are published in FIFA's website and have been anonymised; the same happens with a number of judgements of the Swiss Federal Tribunal (SFT); but it doesn't impede an identification of the parties. Only when, and if, the report of CAS awards is fully developed and confidential cases are excluded from the consideration of case law, it could be spoken about as precedent setting. As things stand today, a party in a dispute before CAS could be in a situation of defencelessness if CAS was to consider itself bound by previous unreported cases. Mitten even throws the idea of a hypothetical challenge based on violation of principle of good faith and equal treatment. ${ }^{57}$ In practice, those active in arbitration before CAS need to extend their network to have access to what Lenard refers to as 'an "underground" library of opinions most utilized in CAS proceedings that were gathered by the lawyers and arbitrators' ${ }^{58}$

\footnotetext{
${ }^{52}$ Mitten (n 4), 61.

${ }^{53}$ McLaren (n 4), 306.

${ }^{54} \mathrm{CAS}$, 'Welcome to the Database of CAS Awards' <http://www.tas-cas.org/jurisprudence-archives > accessed 26 January 2014.

${ }^{55}$ CAS, 'Code 2013 edition’ <www.tas-cas.org/statutes > accessed 26 January 2014.

${ }^{56}$ Lenard (n 2) 178.

${ }^{57}$ Mitten (n 4), 60.

${ }^{58}$ Lenard (n 2) 180
} 
Therefore, lex sportiva as the body of CAS awards is clearly an inappropriate concept. CAS panels don't have the vocation or possibility of setting precedent and the insufficient number of available decisions create unpredictability.

\subsection{Lex sportiva as CAS jurisprudence, general principles and sports regulations}

Some authors understand the concept of lex sportiva not as a noun, but as an adverb which accompanies anything "sport". In that way, Lorenzo Casini includes the "whole complex of norms produced and implemented by regulatory sporting regimes', including IFs and NGBs, in addition to 'principles and rules' created by CAS and international law. ${ }^{59}$ Casini laments that the existence of a lex sportiva, which he also calls global sports law, is not universally accepted. According to this thesis, lex sportiva would be everything and anything produced by sports governing bodies and CAS with influences of international law. Even so, Casini finds enough reasons to postulate a self-regulation based in lex sportiva. ${ }^{60}$ This posture would lead to the risks referred to by Gary Born in relation to the undefined nature of international public policy. ${ }^{61}$ The moment that arbitrators can consider themselves bound by that lex sportiva, the parties in the dispute would encounter a legal dimension not necessarily foreseen.

Richard Parrish's contribution to the concept is in similar broad terms: 'statutes and regulations of federations as interpreted by institutions of alternative dispute resolution', incorporating 'provisions of national, European and international law'. ${ }^{62}$ This fully comprehensive definition doesn't explain why it is necessary to integrate provisions of foreign laws in the idea of a lex sportiva. The uniqueness of lex sportiva needs to come from its character, not from the assimilation of other legal concepts.

With regards to EU sports law - the application of EU law to sporting contexts - Parrish suggests that it 'only patrols the outer limits of the lex sportiva, thus helping to shape the standards with which the CAS develops this law'. ${ }^{63}$ Again, it can be seen a sense CAS-centrism to the lex sportiva. Regardless, the co-habitation between lex sportiva and outside law - whether it may be EU law or other - would be ideal, but the assumption is that there is an agreement as to the actual scope; and that the arbitrators will find the balance between lex sportiva and EU law. With regards to the first aspect, it is clearly not an agreed terminology. With respect to the second point, it doesn't resit the test of the cases in which mandatory provisions of EU have been disregarded as non-applicable.

This kind of lex sportiva has nothing of lex specialis; in reality is an all-absorbing entity of law. It creates more uncertainty than security, which is precisely the reason for distinction.

\subsection{Lex sportiva as rules of the game}

\footnotetext{
${ }^{59}$ Casini (n 14).

${ }^{60}$ Ibid, $2-3$.

${ }^{61}$ Gary B. Born, International Commercial Arbitration (Kluwer Law International 2009) p 2194.

62 Parrish (n 26), 718.

${ }^{63}$ Ibid, 733.
} 
One of the most celebrated awards of the CAS - AEK Athens and SK Slavia Prague vs. Union of European Football Associations (UEFA) (ENIC case) ${ }^{64}$ - is frequently cited to support the concept of lex sportiva as a set of principles. Interestingly, the award uses another expression, lex ludica, but it has been taken mutatis mutandis to be lex sportiva. Be it as it may, it was considered "unwritten principles [...] which national and international sports federations must conform, regardless of the presence of such principles within their own statutes and regulations". ${ }^{65}$ The implication, therefore, is that these principles are somehow above the actual regulations. Similar principle was applied in Boxing Australia v. AIBA pointing that equal treatment and level playing were part of this lex sportiva overriding the agreed regulations. ${ }^{66}$ Accordingly, the sports regulator, i.e. the draftsperson in charge of developing regulations, and perhaps more importantly, the appointed dispute settler, e.g. disciplinary bodies and arbitrators, should be aware of those underlining principles which would override the consensus of the self-regulation.

Some attempt to specify these principles was given by Michael Beloff QC, an arbitrator in the CAS, who considers lex sportiva the body of specialist doctrines and principles of 'application only in a sporting context' to include no intervention with an official's decisions, comfortable satisfaction for sporting disciplinary offences, strict liability rule in relation to doping violations; and the bias towards eligibility in sport competition. ${ }^{67}$ The clear advantages of these principles outlined by Beloff are that they are overwhelmingly accepted in the sport - whether formally organised or not -, they emanate from the rules themselves and they are so intrinsic to sport that its character of lex specialis cannot be disputed. Nonetheless, if lex sportiva is taken to be 'rules of the game', then, following the reflection of Kadens lex mercatoria, you don't need to coin a new term to explain something that has always existed. ${ }^{68}$ Beloff himself alleges that some classical purists would rather use lex ludica for the same principles, but the difference goes beyond purist and purister. ${ }^{69}$ The reason why ENIC used lex ludica seems to be not pedantry, but deliberate intention of establishing the core of the organisation of sport which shall not be regulated from outside the sport.

Calling lex sportiva to the rules of the game is misleading. The same way that lex mercatoria is the law of commerce, lex sportiva needs to be the law of sport. It would be rather pompous if the 'law' component is only the rules created for the better performance of a particular sport. This concept of lex sportiva, therefore, is not satisfactory for insufficient.

\subsection{Lex sportiva as a myth and proposal of a Global Sports Law}

It was referred above the posture of Foster dismissing as a myth the concept of lex sportiva preferring instead a concept of Global Sports Law meaning effectively the body of regulations of the IFs. Similar interpretation -

\footnotetext{
${ }^{64}$ CAS 98/200 [156].

65 Ibid [156].

${ }^{66}$ CAS 2008/O/1455 [42].

${ }^{67}$ Michael Beloff, 'The specificity of sport - rhetoric or reality?'[2012] International Sports Law Review, 9.

${ }^{68}$ Kadens (n 33)

${ }^{69}$ Beloff (n 67)
} 
albeit still calling it lex sportiva - was also adopted by the CAS itself in Andrea Anderson and others $v$. International Olympic Committee (IOC), where the panel stated that the body of regulations would be precisely the starting point of any attempt to demonstrate applicability of lex sportiva to a matter. ${ }^{70}$

This last view seems to be more appropriate. Firstly, it identifies the distinctive elements of the concept. Second, it is supported in material regulations, those adopted by the IFs. Thirdly, it gains the consideration of system when it is interpreted consistently.

The difficulty with the proposition of Foster is the term itself. Global Sports Law is useful in so far as it differentiates it from, for example, European Sports Law, National Sports Law and other instances, but it risks creating confusion. Where European Sports Law can be easily visualised as the body of European law applicable to sport, or National Sports Law as the law applicable to sport in each different country, Global Sports Law evokes more regulations of IFs than general principles inferred from those regulations. In other to rebate the misconceptions of lex sportiva, it is necessary to propose an alternative fit-for-purpose definition. Otherwise there is no debate, there is just division. To address this, the next section proposes a definition of lex sportiva.

\section{Defining lex sportiva}

As seen above, there is no agreement in the conceptualisation of lex sportiva. At the same time, it cohabits with a number of other theoretical notions which go undisputed: rules of the game (or lex ludica, for those so purist), CAS jurisprudence, sports regulations. All these labels convey an idea and have autonomous identity. Even those authors who provide a comprehensive and logical suggestion, refuse the term of lex sportiva. Therefore, one way to overcome that debate would be to provide an adequate definition, not a charter, of lex sportiva.

Neither "general principles of law applicable to sports" or "sports regulations, laws and general principles of law" are usable or practical definitions. There is no reason for sport to expect a different application of the general legal principles or laws, and the sports regulations, while common in some aspects, are result of the agreement of its stakeholders. Put it simply, a hockey player cannot be expected to learn the regulations applicable to tennis or basketball because it may apply to him or her on the basis they all are sports.

The proposed definition for lex sportiva would be "general principles of the regulations of sport shared by the sports community". This notion can be applied by dispute resolution mechanisms - whether it may be the CAS or any other arbitration body or disciplinary tribunal - but it doesn't make it dependent of them nor needs its recognition in order to be enforceable. Very much like a custom legally enforceable, the principles shared by the regulations of sport are easily recognised and expected.

This kind of lex sportiva would be the principle integrity in sport (reflected in the fight against doping and against undue influence in the result of a game by way of betting), fair play, and competitive balance of any competition. Furthermore, this idea of lex sportiva doesn't exclude other non-sport related organisations from its application and assistance. Global Sports Law, related exclusively to the regulation of International Sports Federations and

\footnotetext{
${ }^{70}$ CAS 2008/A/1545 [66].
} 
the harmonisation that the CAS makes of it would sit in parallel to these principles. That lex sportiva would not sit in the apex of the legal pyramid but it would inspire the regulation of sport.

\section{Conclusion}

Lex sportiva can be a very useful concept which would vindicate a high degree of specialisation within the sports and the sports law. So much so that a lex sportiva as principles generated from within would be a significant tool of homogenisation of the regulations of sport and protection of the core of self-regulation that the outside world should respect. On the contrary, CAS-centrism and claims for a special treatment of everything sport would convert lex sportiva a purely academic debate when not an excuse for the law to fix what it is not broken.

The definition of lex sportiva proposed in this article, "general principles of the regulations of sport shared by the sports community" has in common a respect for self-regulation and respect for mandatory law applicable in a case by case basis. That lex sportiva is easy to understand by those involved in sport, acceptable by those outside of it and applicable by any decision maker involved in a sports dispute. 


\section{Reference list}

\section{$\underline{\text { Articles }}$}

- $\quad$ Beloff, M., The specificity of sport - rhetoric or reality? (International Sports Law Review 2012)

- Beloff, M. and Beloff, R., The Field of Play in Hetherington, S. (ed), Halsbury's laws of England centenary essays (LexisNexis Butterworths 2007)

- Casini, L., The Making of a Lex Sportiva: The Court of Arbitration for Sport 'Der Ernährer' (Social Science Research Network 2010)

- Foster, K., Is there a global sports law? (Entertainment and Sports Law Journal 2003)

- Foster, K., Lex Sportiva and Lex Ludica: The Court of Arbitration for Sport's Jurisprudence (Entertainment and Sports Law Journal 2005)

- Hatzimihail, N. E., The Many Lives — and Faces - of Lex Mercatoria: History as Genealogy in International Business Law (Law and Contemporary Problems 2008)

- $\quad$ Kadens, E., The Myth of the Customary Law Merchant (Texas Law Review, 2012)

- $\quad$ Lenard, M., The Future of Sports Dispute Resolution (Pepperdine Dispute Resolution Law Journal 2009)

- McLaren, R. H., Twenty-Five Years of the Court of Arbitration for Sport: A Look in the Rear-View Mirror (Marquette Sports Law Review 2010)

- Mitten, M. J., Judicial Review of Olympic and International Sports Arbitration Awards: Trends and Observations (Pepperdine Dispute Resolution Law Journal 2009)

- Mitten, M. J., and Opie, H., Sports Law”: Implications for the Development of International, Comparative, and National Law and Global Dispute Resolution (Tulane Law Review 2010)

- $\quad$ Parrish, R., Lex sportiva and EU sports law (European Law Review 2012)

- $\quad$ Ravjani, A., The Court of Arbitration for Sport: A Subtle Form of International Delegation (Journal of International Media and Entertainment Law 2009)

- Rodríguez Fernández, M., Reconocimiento de la lex mercatoria como normativa propia y apropiada para el comercio internacional (Revista e-mercatoria 2012)

- Segan, J., Does the Court of Arbitration for Sport need a "Grand Chamber” (Blackstone Chambers Sports Law Bulletin 2013)

- Weston, M. A., Simply a Dress Rehearsal? U.S. Olympic Sports Arbitration and De Novo Review at the Court of Arbitration for Sport (Georgia Journal of International and Comparative Law 2009)

\section{$\underline{\text { Books }}$}

- $\quad$ Born, G., International Commercial Arbitration (Kluwer Law International 2009)

- $\quad$ Born, G., International Arbitration and Forum Selection Agreements: Drafting and Enforcing (Kluwer Law International 2013)

- Merryman, J. H., The civil law tradition: an introduction to the legal systems of Western Europe and Latin America (Stanford : Stanford University Press 1969) 
- Blackaby, N. and Hunter, M. and Redfern, A, Redfern and Hunter on International Arbitration (Oxford University Press 2009)

- Waincymer, J., Procedure and evidence in international arbitration (Kluwer Law International 2012)

\section{Online document}

- CAS, 'Code 2013 edition' <www.tas-cas.org/statutes> accessed 26 January 2014

- WADA, 'World Anti-Doping Code' <www.wada-ama.org/en/World-Anti-Doping-Program/Sportsand-Anti-Doping-Organizations/The-Code/> accessed 27 January 2014.

\section{$\underline{\text { Cases }}$}

\section{Court of Arbitration for Sport}

- Fédération Internationale de Football Association (FIFA) \& World Antidoping Agency (Advisory opinion), CAS 2005/C/976 \& 986

- AEK Athens and SK Slavia Prague vs. Union of European Football Associations (UEFA), CAS 98/200

- Andrea Anderson and others v. International Olympic Committee (IOC), CAS 2008/A/1545

- Boxing Australia v. AIBA, CAS 2008/O/1455

- Canadian Olympic Committee (COC) \& Beckie Scott v. International Olympic Committee (IOC), CAS 2002/O/373

- Club Atlético Peñarol c. Carlos Heber Bueno Suarez, Cristian Gabriel Rodríguez Barrotti \& Paris SaintGermain, TAS 2005/A/983\&984

- FC Shakhtar Donetsk (Ukraine) v. Mr. Matuzalem Francelino da Silva (Brazil) \& Real Zaragoza SAD (Spain) \& FIFA, CAS 2008/A/1519 \& 1520

- International Association of Athletics Federations (IAAF) v. USA Track \& Field, CAS 2004/A/628

- The Gibraltar Football Association (GFA)/Union des Associations Européennes de Football (UEFA), CAS 2002/O/410

- Wigan Athletic FC v/ Heart of Midlothian, Heart of Midlothian v/ Webster \& Wigan Athletic FC and Webster v/ Heart of Midlothian, CAS 2007/A/1298, 1299 \& 1300

\section{English Courts}

- Combe v Combe [1951] 2 KB 215, (1951) 1 All ER 767

- Cookson v Harewood [1932] 2 K.B. 478, 482

- Enderby Town Football Club Ltd. v Football Association Ltd [1971] Ch. 591, [1970] 3 W.L.R. 1021

- McInnes v Onslow-Fane and Another [1978] 1 W.L.R. 1520

\section{Privy Council}

- Calvin v Carr [1979] 2 W.L.R. 755 